\title{
RESEARCH PAPER \\ An ecophysiographic approach for Araucaria araucana regeneration management
}

\author{
Fernando Drake ${ }^{1}$, Juan Ramón Molina ${ }^{2}$, and Miguel Ángel Herrera ${ }^{2}$ \\ ${ }^{1}$ Departamento de Manejo de Bosques y Medioambiente, Facultad de Ciencias Forestales, Universidad de \\ Concepción, Casilla 160-C, Concepción, Chile. \\ ${ }^{2}$ Departamento de Ingeniería Forestal, Escuela Técnica Superior de Ingeniería Agronómica y de Montes, \\ Edificio Leonardo da Vinci, Universidad de Córdoba, ES-14071, Córdoba, España.
}

\begin{abstract}
F. Drake, J.R. Molina, and M.Á. Herrera. 2012. An ecophysiographic approach for Araucaria araucana regeneration management. Cien. Inv. Agr. 39(1): 159-176. Chilean temperate forests are dominated by Nothofagus and Araucaria araucana species. Despite A. araucana not being at imminent risk of extinction, its cultural value and the associated environmental services and landscape goods have an important role for the conservation of this native forest. In some areas, the future conservation of A. araucana is a cause of great concern given its management prohibition and regeneration limitation due to slow growth, canopy tree competition and dense understory. The above characteristics make this species most susceptible to some disturbances, such as livestock, wildlife and human pressures. Therefore, sustainable management of $A$. araucana forests requires the assessment of its regeneration condition. The objective of this research was to apply multivariable analysis techniques in search of the most relevant parameter for Araucaria regeneration. This study used the following methods: principal component analysis (PCA), forward stepwise regression modeling and Maxent modeling. By PCA, it was possible to reduce the dimension to six-dimensional with a variance explanation of greater than $75 \%$. The multivariable regression model, known as model 7 , was the best compromise between the coefficient of determination and model size (number of independent variables). Incorporating a maximum entropy trend improved model performance. A spatial prediction was obtained by summing the contributions of statistical methods and the geographic information system (GIS). The GIS increased the flexibility of the proposed model, which enabled an extrapolation to other areas at different spatial and temporal scales.
\end{abstract}

Key words: Maxent model, Nothofagus species, seedling establishment, seedling tree.

\section{Introduction}

Chilean forests are one of the most biodiverse forests in the world (Marticorena and Quezada, 1985). In the last 100 years, thousands of hectares

Received December 20, 2010. Accepted September 15, 2011. Corresponding author: fdrake@udec.cl of the most endemic, interesting and wonderful forests have been destroyed by men. In the case of Chile, some authors have reported that native forest destruction began in the $16^{\text {th }}$ century with the Spanish conquest (Donoso and Lara, 1995, Torrejon and Cisternas, 2003). Subsequently, millions of hectares were burnt to prepare the land for agriculture in the 1950s (Otero, 2006). 
Araucaria araucana (Mol.) K. Koch is a relict conifer in South America's temperate forests (Tortorelli, 1956, Veblen, 1982, Bekessy et al., 2004, Donoso, 2006). Araucaria forests are found between $37^{\circ}$ and $41^{\circ} \mathrm{S}$ on both sides of the Andean Mountain Range in Chile and Argentina (Veblen, 1982; Donoso, 1993, Drake et al., 2009). Annual precipitation varies between 800 and $4,000 \mathrm{~mm}$ per year (Donoso, 2006) in this region due to its large and narrow distribution. In Chile, A. araucana usually forms mixed stands with Nothofagus obliqua (Mirb. Oerst. var.) at lower altitudes, Nothofagus dombeyi (Mirb. Oerst.) at medium altitudes and Nothofagus pumilio (Poepp. et Endel. Krasser) at higher altitudes (Rodríguez et al., 1983). In Chile, A. araucana covers 253,715 ha (Drake, 2004) representing approximately $60 \%$ of the total area in which this species is found (Donoso, 2006). In Chile, there are two restricted habitats: the Andean Mountain Range and the Chilean Coastal Range (Bekessy et al., 2004). In the Andean Mountain Range, $A$. araucana occupies an area between $37^{\circ} 30^{\prime}$ and $39^{\circ} 30^{\prime} \mathrm{S}$ (Biobío, Araucanía and Los Lagos regions). In the Chilean Coastal Range, $A$. araucana is situated at latitudes between $37^{\circ} 20^{\prime}$ and $38^{\circ} 40^{\prime} \mathrm{S}$ (Donoso, 1993, Enright and Hill, 1995, Drake et al., 2009).

A. araucana is established as a representative symbol of the Chilean forest biodiversity because of its cultural and social importance (Donoso and Lara, 1995, Aagesen, 1998, Donoso, 2006). This species is a primary source of food and income for the Mapuche Pewenche community (Maletti 1997, Bengoa, 2000, Azocar et al., 2005). The Pewenche community obtains edible plants, firewood, livestock shelter and construction materials from these forests (Ladio, 2001, Aagesen, 2004). Native forests also offer important environmental services (Schmidt and Lara, 1985, Hoffmann et al., 2001) and landscape goods according to the presence of century- and millennium-old trees (Heusser et al., 1988). A. araucana is listed as a vulnerable species (IUCN, 1996) and is a protected species under Chilean law, consolidating its protection and prohibiting its cutting (Supreme Decree 43 and Native Forest Law).
The regeneration behavior for shade-tolerant gymnosperms such as A. araucana is consistent with the regeneration hypothesis associated to the competition/colonization model and spatial patterns (Bond, 1989). Under this theoretical framework and based on the dynamics of $A$. araucana/Nothofagus forests, there is direct influence of the regeneration condition and disturbance histories (Veblen, 1982, Burn, 1993). A. araucana can colonize disturbed areas, such as volcanic ash deposition and lava flows, and survive under suppressed conditions and wildfire (Veblen, 1982; Donoso et al., 2008). Wildfire is the most common worldwide disturbance and has been shown to be the key disturbance factor controlling the dynamic of $A$. araucaria/Nothofagus forests (Veblen, 1982; González et al., 2005, 2010). Temperate forest species have developed mechanisms, such as resprouting, fire-girdled stems or thick bark, to survive (Montaldo, 1974, Veblen et al., 1995a, 1995b). The presence of thick bark on $A$. araucana trees is a special adaptation to survive fire conditions. A. araucana trees can regenerate due to their thick bark (Burns, 1993, González et al., 2005, González and Veblen, 2007) if these trees establish immediately after a fire that kills canopy trees (Veblen, 1982; Burns, 1991).

A. araucana is known for its conservative strategy because of its long-lived status (more than 1,000 years) and slow growth (Mutarelli, 1966, Burns, 1991, Donoso, 2006). Seedling establishment may be limited by masting, seed predation and understory vegetation effects (Sanguinetti and Kitzberger, 2009). A. araucana has a cone production masting pattern that is environmentally triggered, intermittent, moderately fluctuating, and regionally synchronous (Sanguinetti and Kitzberger, 2008). Although seed production depends on A. araucana mast year (Sanguinetti and Kitzberger, 2008, Donoso, 2008), the maximum seed production is obtained when the stand age is more than 40 years old (Donoso, 1993) and when the tree occupies the dominant layer in the canopy cover (Enright and Hill, 1995, Enright et al., 1999, Drake, 2004). Austral parakeets (Enicognathus 
ferrugineus) are the primary predispersal predators of A. araucana seeds (Finckh and Paulsch, 1995). Parakeets handle seeds different in mast and intermast years because they drop fewer slightly damaged seeds when production is low (Shepherd et al., 2008). A. araucana seedlings tend to establish mainly beneath parent trees due to the limited dispersal range of the large seeds (Caro, 1995, Sanguinetti and Kitzberger, 2009). If $A$. araucana seedlings colonize immediately in gaps and open areas created by dead trees, they can develop into the canopy layer (Schmidt 1977, Drake 2004). Although some authors have indicated that dense Chusquea understory tends to reduce $A$. araucana seedling establishment (Finckh and Paulsch, 1995, Donoso, 2008, Mujica et al., 2009), other authors have suggested that this situation is not only related to Chusquea competition but also to seed predation (Sanguinetti and Kitzberger, 2009, Sanguinetti and Kitzberger, 2010). A. araucana forests are strongly altered by animal, mainly Sus scrofa Linnaeus, and human pressures (Sanguinetti and Kitzberger, 2008, 2010).

The forest dynamics of mixed stands have been studied extensively (Veblen, 1982, Rodríguez et al., 1983, Burns, 1991, Finckh and Paulsch, 1995, Donoso, 2003, 2006, González and Veblen, 2007, Sanguinetti and Kitzberger, 2008). Despite the prohibition of $A$. araucana management, Drake et al. (2005) recommended sustainable management actions to improve the stand structure and seedling establishment. The present study documented the patterns of vegetation on private land in the Andean Mountain Range in Southern Central Chile. This study aimed to develop an objective and simple model of $A$. araucana stand development that incorporates the regeneration condition. This study utilized tree mensuration, forest characterization, ecological variables and physiographic variables according to the geographic information system (GIS) to define sustainable management recommendations for each stand on the private land. The environmental characteristics and their relation to the regeneration condition were examined. According to other studies (Drake et al., 2005, Mujica et al., 2009), the present study considered the hypothesis that Chilean law and forest policies should strongly consider sustainable management of $A$. araucana and should avoid ecological traditional principles, such $A$. araucana area preservation and complete cutting prohibition.

\section{Materials and methods}

\section{Study area}

A. araucana occupies three administrative regions of Chile: the Biobío Region, Araucanía Region and Los Ríos Region (Figure 1). The study area is located in Melipeuco County in the Araucanía Region, and it covers 255.1 hectares. The sampled area was 108.76 hectares, which was the proportion of the private land where $A$. araucana trees were present.

Although the annual precipitation of this area varies between 1,500 and $2,500 \mathrm{~mm}$, the climate is temperate with dry summer months. The temperature is $2^{\circ} \mathrm{C}$ for the coldest month and $23^{\circ} \mathrm{C}$ for the hottest month. The lithology is predominantly volcanic type, such as volcanic ash deposition in lava flows. These soils have a depth of up to 1.25 m. A. araucana elevation ranges between 1,150 and 1,500 meters. Although there is a small area with a slope greater than $80 \%$, the study area is characterized by wavy topography with a mean slope close to $15 \%$.

The vegetation is occupied by mixed Araucaria/N. Dombeyi/N. pumilio forests. In the upper areas, N. pumilio and Nothofagus antarctica (G. Forst) dominate the vegetation, forming pure stands. The understory is dominated by Chusquea quila (Mol.) Kunth, Drimys winteri J. R. et G. Forster var. andina Reiche, Desfontainia spinosa Ruiz et Pav., Azara lanceolata, Hook. f. Berberis pearcei, Chiliotrichium rosmarinifolium Less, Maytenus disticha Hook. f. and some herbaceous plants, such as Valeriana lapathifolia Vahl. The forest 


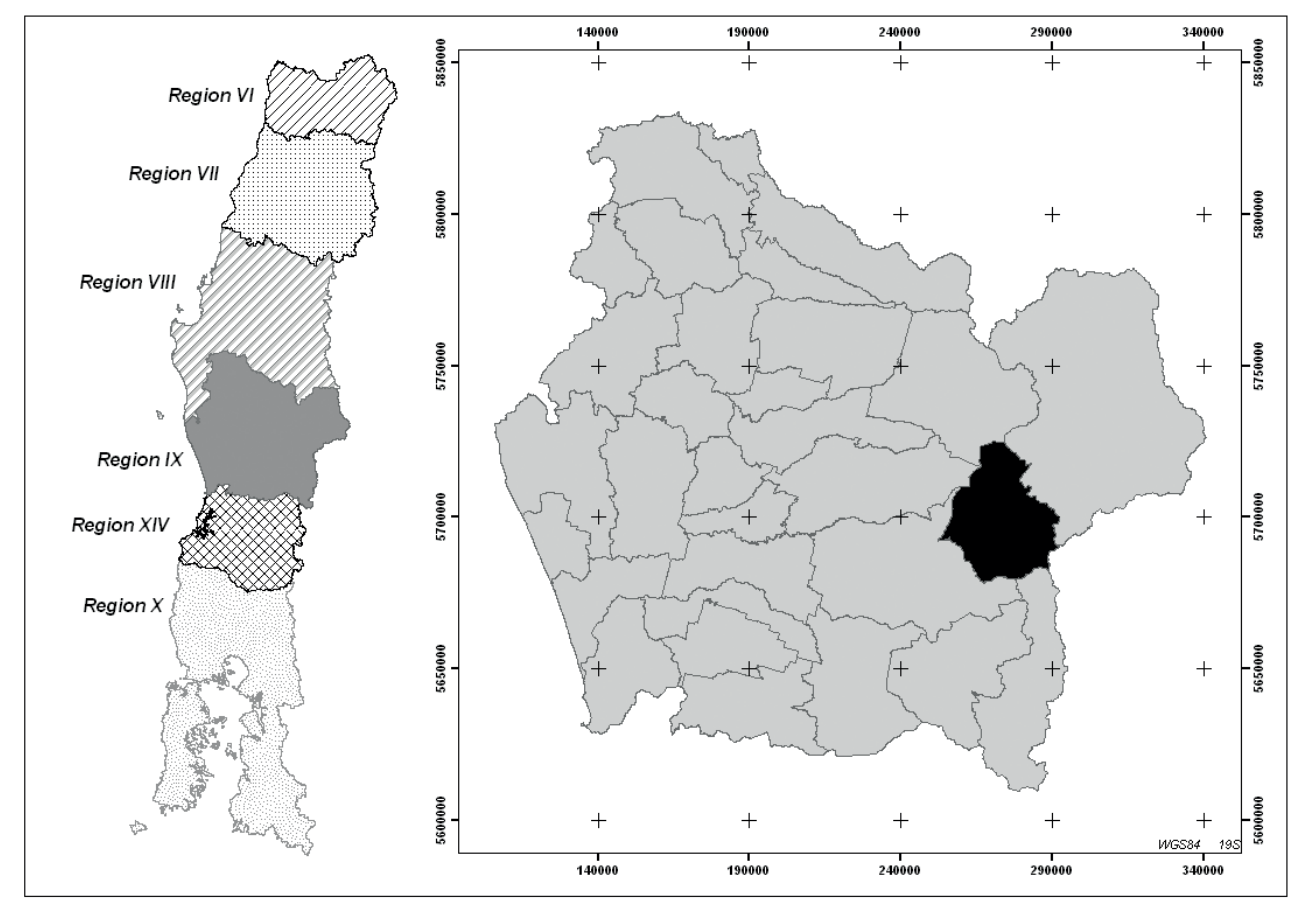

Figure 1. Study area location (meters).

understory generally has a dense layer of C. quila, an aggressive and abundant species in Southern Chile. The dense layer reached up to $1.3 \mathrm{~m}$ in the majority of the sampling units.

\section{Field inventory}

In the study area, there was no evidence of recent disturbances (last 50 years), such as forest fires or volcanic activities. Only trees falling by strong winds were found. The forest inventory design and stratification were developed using aerial photographs and GIS from a private air flight. A preliminary sampling was carried out with the help of the above cartographic information to estimate forest variability in relation to vegetation structure.

An analysis of variance (ANOVA) was used to determine if significant differences $(\mathrm{P} \leq 0.05)$ existed in the vegetation structure (stand density, Araucaria density, Araucaria diameter and
Araucaria height). If significant differences were detected, Tukey's HSD test was performed to determine which specific vegetation characteristic was different.

The sampling units were circular plots of 1,000 $\mathrm{m}^{2}$ according to the inventory results of the surrounding area where crown diameters between 9.75 and $13.55 \mathrm{~m}$ were found (León and Villarroel, 2004), and the plot optimization was based on forest characterization (Freese, 1961, Zeide, 1980). This plot size had some limitations because of the presence of some seedling trees near the plot borders. As a consequence, some $A$. araucana seedlings were either present inside or outside of the plot. The forest inventory design was based on a cost-benefit analysis (Condés and Martínez Millán, 2001) according to its private condition and the lack of economic profitability.

Regeneration information was collected by random and square $100 \mathrm{~m}^{2}$ subplots containing A. araucana and other species seedlings. The 
seedling number was calculated by averaging the mean seedling number over the $1,000 \mathrm{~m}^{2}$ plot. Model variables were expressed as the number of seedlings per hectare to allow the model to be applied independently of the plot size. All seedlings were classified by three diameter classes $(<1 \mathrm{~cm}$, $1-5 \mathrm{~cm}$, and $>5 \mathrm{~cm})$ and three height classes $(<$ $50 \mathrm{~cm}, 50-130 \mathrm{~cm}$, and $>130 \mathrm{~cm}$ ) according to previous A. araucana approaches (Cavieres, 1987, Divasto, 2003, Drake, 2004). Seedling height has a low correlation with seedling age due to the different abilities of species to respond to shade or light stress. González (1998) reported that the average annual height growth for A araucana ranges between 3.10 and $3.55 \mathrm{~cm}$. According to this hypothesis, it was possible to establish a relation between height classes and to estimate age without the need of tree-ring measurement. Thus, A. araucana seedlings less than $50 \mathrm{~cm}$ generally corresponded to plants less than 15 years old.

We tested different types of variables: tree mensuration, forest characterization, ecological variables and physiographic variables (Table 1).
All variables were organized in a GIS database at a digital elevation model with an original 30-m resolution. Forest characterization variables, such as stand density, A. araucana density, canopy composition and seedling tree presence, were complemented by ecological variables, such as shrub coverage, A. araucana seedling number and Nothofagus seedling number. Stand density (DEN) and Araucaria density (ARA) were obtained from the forest inventory and were expressed as the number of trees per hectare. Thus, the model can be applied independently of the plot size. A binomial variable (COM) representing the canopy composition was created (class $0=N$. dombeyi and class $1=N$. dombeyi and $N$. pumilio). The SED variable depended on the presence of $A$. araucana trees with maximum seed production (class $0=$ seed tree absence and class $1=$ seed tree presence), which allowed an improvement opportunity for seedling establishment. A "seed tree" was identified as a female tree with a 50-100-cm diameter at breast height (dbh) according to previous studies (Enright et al., 1999, Drake, 2004).

Table 1. Variables used in the modeling experiments.

\begin{tabular}{lcc}
\hline Name & Definition & Units \\
\hline REG & A. araucana seedlings per hectare & seedlings $/$ ha \\
DEN & Number of trees per hectare & Trees ha $^{-1}$ \\
ARA & Araucaria trees per hectare & Trees ha $^{1}$ \\
COM & Canopy composition & Two classes \\
BRU & Shrub coverage & Five classes \\
DIF & Presence of dense and high understory $(>1.3 \mathrm{~m}$ of mean height) & Two classes \\
SED & Presence of seedling tree (50-100 cm of dbh) & Two classes \\
BUF & Araucaria seedlings in the nearest plots (mean value) & Seedlings ha ${ }^{-1}$ \\
COMP & Nothofagus seedlings per hectare & Seedlings ha ${ }^{-1}$ \\
SIZ & Size of largest Araucaria seedling & Three classes \\
SLO & Slope degree & Degree \\
ASP & Aspect degree & Degree \\
POS & Topographic position of the plot & Three classes \\
\hline
\end{tabular}

REG: Araucaria regeneration; DEN: stand density; ARA: Araucaria density; COM: canopy composition; BRU: shrub coverage; DIF: difficulty to seedling establishment; SED: presence of $A$. araucana trees with maximum seed production; BUF: seedling number over surrounding sample units; COMP: Nothofagus regeneration; SIZ: seedling size, SLO: slope, ASP: aspect; and POS: topographical position. 
The following ecological variables were used: shrub coverage, Nothofagus seedling number and A. araucana seedling number. The shrub coverage variable (class $1=$ low coverage to class $5=$ dense coverage) was derived from the Braun-Blanquet method (Braun-Blanquet, 1979). A binomial variable was adopted to create the difficulty of seedling establishment (DIF) according to the shrub height (class $0=$ mean height of less than $1.30 \mathrm{~m}$ and class $1=$ height of more than 1.30 $\mathrm{m})$. The presence of dense and high understory is related to A. araucana seedling establishment (Finckh and Paulsch, 1995, Finckh, 1996, Rechene et al., 2003, Donoso, 2008, Mujica et al., 2009). Nothofagus regeneration was obtained from the forest inventory and was expressed as the number of seedlings per hectare. Current explanations for Nothofagus regeneration success emphasize the advantages on seedling growth rate and seed dispersal (Veblen, 1982; Burns, 1993; Donoso, 1993). The functional differences on gymnosperm and angiosperm growth rates suggest that $A$. araucana will be limited in areas where growth of Nothofagus is important, for example, in isolated habitats (Finckh, 1996; Rechene et al., 2003). One variable based on the regeneration condition in the surrounding area was used to avoid the problems associated with plot size and border effect (for example, seedlings located near the plot border). Mean seedling number (BUF) was calculated by averaging the seedling number (REG) over surrounding sample units (110 m). Finally, the A. araucana regeneration condition depends on the seedling size or seedling age. The same procedure used for the other variables was adopted to create the size variable (SIZ) according to the presence of seedlings less than $50 \mathrm{~cm}$ or 15 years, seedlings between $50-130 \mathrm{~cm}$ or 15-40 years, and seedlings more than $130 \mathrm{~cm}$ or 40 years $($ class $0=$ less than $50 \mathrm{~cm}$; class $1=$ between 50-130 cm; and class $2=$ more than 130 $\mathrm{cm}$ ). When $A$. araucana regeneration is less than $50 \mathrm{~cm}$, seedlings are exposed to competition with shrub species, mainly $D$. winteri var. andina and D. spinosa, and Nothofagus seedlings that colonize gaps faster than Araucaria seedlings. Finally, over 40 years (approximately $130 \mathrm{~cm}$ of height in the study area), seedlings can reach a further crown developing or polewood stage (Cavieres, 1987; Drake, 2004).

The following physiographic variables were used: slope, aspect and topographical position. The slope (SLO) and aspect (ASP) variables were derived from the field plot and validated from the digital terrain model at a $30-\mathrm{m}$ resolution. The aspect variable affects the amount of sunlight the plot receives and is expressed as degrees. In Chilean latitudes, places with a northern aspect tend to be warmer and drier than places with a southern aspect. A categorical variable representing the topographical position (POS) within each sample unit was created (class 1 = valley or lower slope area; class 2 mid-level slope area; and class 3 = upper slope area).

\section{Statistical analysis}

Statistical analysis was realized including the above variables with easy identification for forest managers. With principal component analysis (PCA), a large number of variables can be systematically reduced to a smaller and conceptually more coherent set of variables. These principal components are a linear combination of the original variables. The first principal component usually accounts for most of the variation in the variables and successively within the rest of the components.

To assess the spatial autocorrelation of $A$. araucana regeneration in the models, the following two different predictors were prepared: multivariable regression model and trend, which accounted for spatial autocorrelation of the observed natural regeneration at the landscape level. The multivariable regression model was created in SPSS $10.00^{\circ}$ by a parametric model using a forward stepwise method. Ecological, forest and physiographic variables were used to test modeling alternatives and to provide the best modeling framework. Due 
to the measurement of $A$. araucana regeneration (dependent variable) on seedlings per hectare, the model can be applied independently of the forest inventory. In addition, a trend was created by a geostatistical method, which resulted in a smooth surface capturing coarse-scale pattern of $A$. araucana regeneration based on random field values and their spatial distributions. GARP and Maxent models (geostatistical methods) can test the regeneration of an unsampled area using ecological niche-modeling algorithms (Baldwin, 2009; Costa et al., 2010). Both methods attempt to identify correlations between the presence or absence of natural regeneration and environmental parameters. Maxent models fit a probability distribution for $A$. araucana regeneration based on the principle that the best explanation of unknown phenomena will maximize the entropy of the probability distribution (Phillips et al., 2006). A given location may be allocated to an absence or presence set depending on whether a given regeneration might or might not be present (binary variable). The environmental variables most closely associated with the presence of regeneration can be extrapolated to similar biotopes to identify the probable spatial patterns of the seedlings. Multivariate data analysis is a crucial part of the methodology (Mota et al., 2002, Moreno et al., 2011). The model starts with a uniform distribution and performs a number of iterations based on the most significant environmental variables until no further improvements in the prediction are made.

Similar to other studies (Moreno et al., 2011), $25 \%$ of the sample plots were used to test whether Maxent predictions (training dataset) were better than random predictions. Maxent models were evaluated using the area under the curve (AUC) of a receiver operating characteristic (ROC) plot on the training and test datasets. Maxent models use the area under the curve (AUC) to evaluate the model statistically and are among the statistics most frequently used to assess ecological modeling (Peterson and Nakazawa, 2008; Baldwin, 2009; Costa et al., 2010, Moreno et al., 2011). According to the Maxent model, each grid cell of the study area predicted to have the best conditions for natural regeneration will have the cumulative value of 1 , and cumulative values close to 0 indicate predictions of unsuitable conditions.

\section{Results and discussion}

\section{Field inventory}

Three stands were identified with 99.07 hectares (81 plots), 3.72 hectares ( 2 plots) and 5.97 hectares (6 plots) according to the stand structure (Table 2 ). The distance among the sample units was calculated as 110 meters according to the square root between each stand area and plot number depending on the standard deviation (Consejería de Medio Ambiente, 2004). Although many additional variables, such as stump diameter (before prohibition of $A$. araucana cutting), crown diameter and understory composition, were collected during the inventory, only a summary of the following five most important variables was presented: canopy composition, stand density, Araucaria density, Araucaria diameter and Araucaria height. The canopy composition was dominated by mixed $A$. araucana/N. dombeyi/N. pumilio forests (Table 2). Although the stand density was significantly reduced in stand 2, Araucaria density was the most variable parameter. The stand diameter was significantly increased in stand 2 as compared to stands 1 and 3. Finally, Araucaria height was significantly reduced in stand 3 .

A. araucana regeneration tended to be less than or equal to 3 seedlings at $72 \%$ of the total sample units $\left(100 \mathrm{~m}^{2}\right)$. The lack of natural regeneration may have been due to seed production and seed predation by rodents. The forest inventory showed that $75 \%$ of the plots were without seedling trees and, consequently, had a low regeneration condition. In $30.34 \%$ of these sampling units, the $A$. araucana trees were in old growth conditions, which resulted in unsuitable seed production. More than 3 A. araucana seedlings per plot (100 $\mathrm{m}^{2}$ ) were associated with the presence of seed- 
Table 2. Average forest stands characteristics.

\begin{tabular}{lccc}
\hline Stand & 1 & 2 & 3 \\
\hline Area (ha) & 99.07 & 3.72 & 5.97 \\
Canopy Composition & A. araucana N. dombeyi, N. pumilio & A. araucana N. pumilio & A. araucana N. dombeyi \\
Stand density (trees/plot) & $30.4( \pm 18.39) \mathrm{a}$ & $17.5( \pm 9.19) \mathrm{b}$ & $37.7( \pm 22.76) \mathrm{a}$ \\
Araucaria density (trees/plot) & $4.4( \pm 3.21) \mathrm{ab}$ & $2.5( \pm 0.70) \mathrm{a}$ & $9.2( \pm 6.82) \mathrm{b}$ \\
Araucaria diameter $(\mathrm{cm})$ & $58.97( \pm 23.73) \mathrm{ab}$ & $84.92( \pm 55.96) \mathrm{a}$ & $48.17( \pm 25.45) \mathrm{b}$ \\
Araucaria height $(\mathrm{m})$ & $23.17( \pm 8.31) \mathrm{a}$ & $24.25( \pm 7.42) \mathrm{a}$ & $19.86( \pm 10.31) \mathrm{b}$ \\
\hline
\end{tabular}

Mean values in a row followed by the same letter are not significantly different $(\mathrm{P} \leq 0.05)$.

ling trees, which was a unique factor and was not enough to explain the observed A. araucana regeneration pattern.

In general, A. araucana regeneration was related to the presence of high Nothofagus regeneration levels. In $91.30 \%$ of the plots with low A. araucana regeneration $(<3$ seedling per plot), more than 7 Nothofagus seedlings were present. In $87.5 \%$ of the plots with more than 100 Nothofagus seedlings, low levels of $A$. araucana regeneration were present. In some plots, there was a good level of regeneration with less than 15 years, but advanced stages of seedling development were not present. A. araucana seedlings with more than 15 years were only present in $13.43 \%$ of the total sample units. Shrub coverage was more than 75 in $79.10 \%$ of the study area. C. quila had an aggressive behavior, reaching up to $1.30 \mathrm{~m}$ (breast height) in $31.34 \%$ of the total sampling units. $A$. araucana regeneration of each plot was related to the surrounding plots (within less than 110 meters). A portion (68.75\%) of the plots that had no $A$. araucana regeneration was surrounded by plots with no or low A. araucana regeneration.

\section{Principal component analysis}

Principal component analysis transformed the original set of variables into a substantially smaller set of uncorrelated variables that represented most of the information in the original dataset. The total variance in the system was $100 \%$, which was the sum of the variances of the thirteen standardized variables. The variance of the first component was $27.7 \%$ (Table 3). Because there were six components, it was possible to explain $76 \%$ of the total variance of the thirteen variables. The remaining components were difficult to assign variance due to the high variability of the dataset. Thus, the first seven components only accounted for $80 \%$ of the variance.

\section{Multiple regression models}

Different regressions were planned to measure the relative goodness of each model using 89 field plots (Table 4). The selection stopped when models could not add improvements according to the coefficient of determination $\left(\mathrm{R}^{2}\right)$, DurbinWatson statistic and Alaike information crite-

Table 3. Estimates of variances associated to principal components and their proportion and cumulative variance.

\begin{tabular}{lccc}
\hline $\begin{array}{l}\text { Principal } \\
\text { Component }\end{array}$ & $\begin{array}{c}\text { Eigenvalue } \\
(\lambda)\end{array}$ & $\begin{array}{c}\text { Proportion } \\
\text { variance }(\%)\end{array}$ & $\begin{array}{c}\text { Cumulative } \\
\text { variance }(\%)\end{array}$ \\
\hline 1 & 3.59 & 27.7 & 27.7 \\
2 & 1.64 & 12.6 & 40.3 \\
3 & 1.42 & 10.9 & 51.2 \\
4 & 1.17 & 9.1 & 60.3 \\
5 & 1.05 & 8.1 & 68.4 \\
6 & 0.98 & 7.5 & 76 \\
7 & 0.83 & 6.5 & 82.4 \\
8 & 0.68 & 5.3 & 87.7 \\
9 & 0.45 & 3.5 & 91.2 \\
10 & 0.34 & 2.7 & 93.9 \\
11 & 0.33 & 2.6 & 96.5 \\
12 & 0.31 & 2.4 & 98.9 \\
13 & 0.13 & 1.1 & 100 \\
\hline
\end{tabular}


rion (AIC). The differences in $\mathrm{R}^{2}$, which is an indicator of model predictability and goodness, and in AIC, which is an indicator of model size, were of particular importance (Burnham and Anderson, 2002). According to the coefficient of determination evaluation, the best performances were obtained with models 1, 7 and 8. Based on AIC, the best performances (lowest values) were obtained with models 14, 9 and 7.

\section{Geostatistical model}

The geostatistical models performed better than the random models in explaining the presence or absence of $A$. araucana regeneration. The performance and stability of the geostatistical models were significantly higher $(\mathrm{P} \leq 0.01)$ than the random models. The AUC values over all models ranged from 0.974 for model 5 to 0.989

Table 4. Multiple regression models.

\begin{tabular}{|c|c|c|c|c|}
\hline Code & Model & $\mathrm{R}^{2}(\%)$ & $\begin{array}{l}\text { Durban-Watson } \\
\text { statistic }\end{array}$ & AIC \\
\hline 1 & $\begin{array}{c}\mathrm{REG}=165.85 * \mathrm{SED}+0.63 * \mathrm{BUF}-0.004 * \mathrm{COMP}+266.1 * \mathrm{SIZ}+ \\
0.44 * \mathrm{ASP}+61.68 * \mathrm{POS}-0.19 * \mathrm{DEN}-3.53 * \mathrm{ARA}-241.22 * \mathrm{COM} \\
-46.90 * \mathrm{BRU}-99.18 * \mathrm{DIF}+10.81 * \mathrm{SLO}\end{array}$ & 82.4 & 2.11 & 468 \\
\hline 2 & $\begin{array}{c}\mathrm{REG}=256.24 * \mathrm{SED}-0.01 * \mathrm{COMP}+335.46 \mathrm{SIZ}++0.46 * \mathrm{ASP}+ \\
110.52 * \mathrm{POS}-0.25 * \mathrm{DEN}-2.86 * \mathrm{ARA}-324.88 * \mathrm{BRU}-43.53 * \mathrm{DIF}\end{array}$ & 49.3 & 1.77 & 705.97 \\
\hline 3 & $\begin{array}{c}\mathrm{REG}=146.95 * \mathrm{SED}+0.65 * \mathrm{BUF}-0.002 * \mathrm{COMP}+0.45 * \mathrm{ASP}+ \\
105.14 * \mathrm{POS}-282.26 * \mathrm{COM}-67.49 * \mathrm{BRU}-331.75 * \mathrm{DIF}+7.99 * \mathrm{SLO}\end{array}$ & 75.1 & 1.90 & 458.18 \\
\hline 4 & $\begin{array}{c}\mathrm{REG}=226.47 * \mathrm{SED}+341.96 * \mathrm{SIZ}+0.58 * \mathrm{ASP}-42.71 * \mathrm{POS}- \\
4.62 * \mathrm{ARA}-557.86 * \mathrm{COM}-293.92 * \mathrm{BRU}+21.05 * \mathrm{SLO}\end{array}$ & 61.2 & 1.85 & 523.48 \\
\hline 5 & $\begin{array}{l}\mathrm{REG}=192.1 * \mathrm{SED}+0.65 * \mathrm{BUF}-0.05 * \mathrm{DEN}-0.8 * \mathrm{ARA}- \\
338.56 * \mathrm{COM}-100.55 * \mathrm{BRU}-291.42 * \mathrm{DIF}+11.47 * \mathrm{SLO}\end{array}$ & 73.5 & 1.98 & 424.76 \\
\hline 6 & $\begin{array}{c}\mathrm{REG}=92.42 * \mathrm{SED}+0.65 * \mathrm{BUF}+214.73 * \mathrm{SIZ}-0.37 * \mathrm{DEN}- \\
149.55 * \mathrm{COM}-58.4 * \mathrm{BRU}-139.8 * \mathrm{DIF}+13.24 * \mathrm{SLO}\end{array}$ & 78.6 & 1.97 & 377.67 \\
\hline 7 & $\begin{array}{c}\mathrm{REG}=139.4 * \mathrm{SED}+0.72 * \mathrm{BUF}+313.17 * \mathrm{SIZ}+0.31 * \mathrm{ASP}+ \\
56.42 * \mathrm{POS}-0.20 * \mathrm{DEN}-2.97 * \mathrm{ARA}+11.67 * \mathrm{SLO}\end{array}$ & 80.4 & 2.15 & 373.41 \\
\hline 8 & $\begin{array}{c}\mathrm{REG}=0.67 * \mathrm{BUF}-0.003 * \mathrm{COMP}+286.44 * \mathrm{SIZ}+0.48 * \mathrm{ASP}- \\
3.16 * \mathrm{ARA}-219.45^{*} \mathrm{COM}-108.19 * \mathrm{DIF}+14.29 * \mathrm{SLO}\end{array}$ & 80.7 & 1.85 & 399.66 \\
\hline 9 & $\begin{array}{c}\mathrm{REG}=252.77 * \mathrm{SED}-0.007 * \mathrm{COMP}+287.63 * \mathrm{SIZ}+0.19 * \mathrm{ASP}+ \\
134.46 * \mathrm{POS}-0.40 * \mathrm{DEN}-430.65 * \mathrm{COM}\end{array}$ & 45.9 & 1.90 & 330.54 \\
\hline 10 & $\begin{array}{c}\mathrm{REG}=178.18 * \mathrm{SED}+0.76 * \mathrm{BUF}-0.007 * \mathrm{COMP}+0.55 \mathrm{ASP}- \\
0.29 * \mathrm{ARA}-144.04 * \mathrm{BRU}-202.4 * \mathrm{DIF}\end{array}$ & 70.8 & 2.22 & 405.98 \\
\hline 11 & $\begin{array}{c}\mathrm{REG}=0.74 * \mathrm{BUF}-0.006 * \mathrm{COMP}+126.68 * \mathrm{POS}-0.83 * \mathrm{ARA}- \\
211.65^{*} \mathrm{COM}-157.59 * \mathrm{BRU}\end{array}$ & 68.6 & 1.85 & 720.45 \\
\hline 12 & $\begin{array}{c}\mathrm{REG}=165.92 * \mathrm{SED}+0.69 * \mathrm{BUF}+0.37 \mathrm{ASP}+167.08 * \mathrm{POS}- \\
272.9 * \mathrm{COM}-349.1 * \mathrm{DIF}\end{array}$ & 74.2 & 1.93 & 411.60 \\
\hline 13 & $\begin{array}{c}\mathrm{REG}=-0.003 * \mathrm{COMP}+0.16 * \mathrm{DEN}+0.05 * \mathrm{ARA}- \\
760.62 * \mathrm{COM}-535.59 * \mathrm{DIF}\end{array}$ & 35.3 & 1.90 & 349.88 \\
\hline 14 & $\begin{array}{c}\mathrm{REG}=0.77 * \mathrm{BUF}+248.31 * \mathrm{SIZ}+0.28 \mathrm{ASP}+102.92 * \mathrm{POS}- \\
0.43 * \mathrm{DEN}\end{array}$ & 76 & 2.021 & 290.45 \\
\hline
\end{tabular}

REG: Araucaria regeneration; DEN: stand density; ARA: Araucaria density; COM: canopy composition; BRU: shrub coverage; DIF: difficulty to seedling establishment; SED: presence of $A$. araucana trees with maximum seed production; BUF: seedling number over surrounding sample units; COMP: Nothofagus regeneration; SIZ: seedling size, SLO: slope, ASP: aspect and POS: topographical position. 
for model 1. Model 1 performed better than model 7 when using training data (Table 5). However, model 7 was more stable than model 1 when using test data. A second group with reasonably good models included models 2 and 4.

Table 5. Area under the curve (AUC) for the different models in training and test data set.

\begin{tabular}{lcc}
\hline Model & Training data AUC & Test data AUC \\
\hline 1 & 0.989 & $0.963( \pm 0.013)$ \\
2 & 0.987 & $0.968( \pm 0.012)$ \\
3 & 0.982 & $0.979( \pm 0.006)$ \\
4 & 0.985 & $0.975( \pm 0.011)$ \\
5 & 0.974 & $0.889( \pm 0.020)$ \\
6 & 0.975 & $0.920( \pm 0.015)$ \\
7 & 0.988 & $0.967( \pm 0.011)$ \\
8 & 0.946 & $0.923( \pm 0.033)$ \\
9 & 0.987 & $0.952( \pm 0.021)$ \\
10 & 0.976 & $0.959( \pm 0.015)$ \\
11 & 0.843 & $0.779( \pm 0.070)$ \\
12 & 0.981 & $0.963( \pm 0.015)$ \\
13 & 0.82 & $0.534( \pm 0.106)$ \\
14 & 0.936 & $0.883( \pm 0.051)$ \\
\hline
\end{tabular}

Table 6 shows the contribution of each variable within the selected models (model contribution in Maxent). The seedling tree presence (SED) and aspect (ASP) variables had the highest contributions in the models, followed by the SIZ and BUF variables. Stand density (DEN) and Araucaria density (ARA) also had an important role. The contributions of canopy composition (COM) and shrub coverage (BRU) were low, and these variables were not retained for more than one-third of the models.

\section{Management implications}

The study of regeneration conditions is essential for forestry management at the landscape level to preserve $A$. araucana cultural and social importance (Donoso and Lara, 1995, Aagesen, 1998, Donoso, 2006). The field inventory allowed the study area to be generalized as an area with low regeneration conditions. Although seedling establishment may be limited by masting, seed

Table 6. Contribution (percentage) of each variable within the selected models.

\begin{tabular}{|c|c|c|c|c|c|c|c|c|c|c|c|c|}
\hline Model & DEN & ARA & $\mathrm{COM}$ & BRU & DIF & SED & BUF & COMP & SIZ & SLO & ASP & POS \\
\hline 1 & $*$ & $*$ & 0 & $*$ & $*$ & $* * * * *$ & $*$ & $*$ & $*$ & 0 & $* * *$ & $*$ \\
\hline 2 & $*$ & $*$ & - & 0 & $*$ & $* * * * * *$ & - & $*$ & $* *$ & - & $* * *$ & $*$ \\
\hline 3 & - & - & 0 & 0 & $*$ & $* * * * * * *$ & $*$ & $*$ & - & $*$ & $* * *$ & $*$ \\
\hline 4 & - & $*$ & $*$ & $*$ & - & $* * * * * *$ & - & - & $* *$ & $*$ & $* * *$ & $*$ \\
\hline 5 & $*$ & $*$ & $*$ & $*$ & * & $* * * * * * * * *$ & $*$ & - & - & $*$ & - & - \\
\hline 6 & $*$ & - & $*$ & 0 & 0 & $* * * * * * * *$ & $*$ & - & $* *$ & $*$ & - & - \\
\hline 7 & $*$ & $*$ & - & - & - & $* * * * * *$ & $*$ & - & $*$ & $*$ & $* * *$ & $*$ \\
\hline 8 & - & $*$ & 0 & - & $*$ & - & $* *$ & $*$ & $* * *$ & $*$ & $* * * * * *$ & - \\
\hline 9 & $*$ & - & $*$ & - & - & $* * * * * *$ & - & $*$ & $* *$ & - & $* * *$ & $*$ \\
\hline 10 & $*$ & - & $*$ & - & - & $* * * * * * *$ & - & $*$ & $* *$ & - & $* * *$ & $*$ \\
\hline 11 & - & $* *$ & $*$ & $*$ & - & - & $* * * * *$ & $*$ & - & - & - & $* *$ \\
\hline 12 & - & - & 0 & - & $*$ & $* * * * * * *$ & $*$ & - & - & - & $* * *$ & $*$ \\
\hline 13 & $* * * * *$ & $* * * *$ & $*$ & - & * & - & - & $* *$ & - & - & - & - \\
\hline 14 & $*$ & - & - & - & - & - & $* *$ & - & $* * *$ & - & $* * * * *$ & $*$ \\
\hline
\end{tabular}

*, <10\%; **, 10-20\%; ***, 20-30\%; ****, 30-40\%; *****, 40-50\%; ******, 50-60\%; *******, 60-70\%; ********, 70-80\%; $* * * * * * * * *, 80-90 \%$; 0, variable proposed but not retained in the model; and -, variable not proposed in the model.

REG: Araucaria regeneration; DEN: stand density; ARA: Araucaria density; COM: canopy composition; BRU: shrub coverage; DIF: difficulty to seedling establishment; SED: presence of $A$. araucana trees with maximum seed production; BUF: seedling number over surrounding sample units; COMP: Nothofagus regeneration; SIZ: seedling size, SLO: slope, ASP: aspect; and POS: topographical position. 
predation and understory competition (Donoso, 2008, Mujica et al., 2009, Sanguinetti and Kitzberger, 2009, Sanguinetti and Kitzberger, 2010), stand 2 presented serious problems for seed production due to the presence of less than $25 \mathrm{~A}$. araucana trees per hectare. In addition, more of these trees did not obtain a suitable seed production because they were not identified as female trees in the $50-100-\mathrm{cm}$ diameter class according to previous studies (Enright et al., 1999; Drake, 2004).

The absence of disturbances in the study area is the main factor controlling the dynamics of the Araucaria/Nothofagus forests (Schmidt, 1977, Schmidt et al., 1980, Veblen, 1982, Donoso, 1993). A. araucana seedling establishment can be influenced by fast-growing species and dense understory. In the study area, the presence of Nothofagus seedlings with more than $50 \mathrm{~cm}$ of height was related to the absence or a low level of $A$. araucana regeneration. Although the above trends can be explained by different seed dispersion conditions, angiosperm dominance and gymnosperm persistence (Bond, 1989), the high competition of Nothofagus seedlings and Chusquea understory may be explained by the limited $A$. araucana seedling establishment (Mujica et al., 2009) and by the isolated stands (Finckh, 1996; Rechene et al., 2003).

Despite the many factors that influence the $A$. araucana regeneration condition (Veblen, 1982; Donoso, 1993, 2006), the first seven components (PCA) explained $82.4 \%$ of the variance in the thirteen variables. The dimensionality of the observations was reduced from thirteen to seven variables showing a $17.6 \%$ variance reduction. The multivariable statistical analysis was designed based on the PCA results. Model 7 was the best compromise between model goodness and mode size (coefficient of determination, Durbin-Watson statistic, and Alaike information criterion) among the thirteen models tested. Although some authors have recommended the use of different AIC methods based on the information theory (Burnham and Anderson, 2002), the ranking of the selection methods in the present study contradicted the AIC methods but was similar to other regression analysis studies (Maggini et al., 2006). AIC is too permissive in providing the lower bound for the set of adequate models (Kuha, 2004).

Alternatives to regression analysis have been developed in recent years based on models where variables do not need to be properly selected but are given a decreasing weight according to their influence on the model. Several methods, such as GARP or Maxent models, can predict natural regeneration based on random field values and the spatial distribution of the regeneration. The differences between the GARP and Maxent models can be observed in their potential distribution results. While Maxent models produce more detailed fine-grained predictions and are additive, GARP models tend to produce overpredictions (Phillips et al., 2006; Baldwin, 2009; Costa et al., 2010). The general spatial trend significantly improved model performance and stability. According to the classification of Swets (1988) (0.5-0.7 poor discrimination ability, $0.7-0.9$ reasonable discrimination, and 0.9-1 very good discrimination), the area under the curve (AUC) obtained in the different models showed very good discrimination ability.

There is not an objective rule concerning the choice of which variables to limit. A common practice is to choose the most influential variables, such as seedling tree and aspect, to predict the spatial patterns of regeneration. The variables in model 7 were limited due to their statistical results ( $\mathrm{R}^{2}$, Durbin-Watson statistic, AIC and AUC). Seedling tree presence represented the main environmental variable, with a model contribution (as defined in the Maxent model) reaching $80 \%$ in some cases. The aspect variable was also important. The SIZ variable can be used as a surrogate for the stand structure as information for the competition level for both the ground and canopy layers. A. araucana seedlings with more than 15 years were present in areas 
with less competition, which were areas where Araucaria seedlings colonized more successfully. SIZ variable contribution was particularly important (up to 10\%) for models 2, 4, 6, 8, 9, 10 and 14. Schwarz et al. (2003) provided empirical evidence that factors, such as competition or seed dispersal, have an important role in determining spatial patterns of regeneration for many tree species in forested landscapes. In the present study, this neighboring factor was expressed by the BUF variable, which mainly accounted for plot size limitation, gap distribution and surrounding seedling tree presence. The contribution of the BUF variable was relatively low compared with the other variables (up to $10 \%$ for models 8,11 and 14), but the contribution of the BUF variable was still significant. In the study area, a good level of $A$. araucana regeneration was confined to aggregated sample units, and the regeneration distribution was frequently identified by clumped spatial distribution.

Several authors (Zhang et al., 2005) have recommended the use of the geography information system (GIS) and weighted regression to show a potential trend when ecological and/or statistical evidence of spatial autocorrelation is found. Technical recommendations can be identified with the help of GIS by the analysis of the following parameters: current regeneration condition, seedling tree presence, A. araucana density and slope (Figure 2). Protection from disturbances existed in clumps with high or medium regeneration levels and a slope greater than $15 \%$. Treatments were not recommended in areas with a mean slope greater than $15 \%$, poor regeneration and a lack of seeding trees due to high costs (Table 7). In clumps with a mean slope of less than $15 \%$, it was suggested to remove trees in the old-growth stage in a series of Nothofagus cuttings to establish a cohort of seeding trees in an advanced regeneration stage (shelterwood method). The shelterwood method is related to improvement cutting or regenerative cutting. The former cutting method was suggested to remove the old trees and create favorable conditions for A. araucana seedling establishment. Improvement cuttings are aimed primarily at controlling the stand growth by adjusting stand density and/or canopy composition. Finally, in poor regeneration areas with a mean slope less of than $15 \%$, the technical recommendation depended on the seeding tree presence. When seeding trees existed, Nothofagus regenerative cutting and brushing out was suggested. If seeding trees were absent, clearing and clumping enrichment through plantation was suggested. Thus, there was an $A$. araucana plantation in the study area with an $85 \%$ successful survival rate in living plants after 23 years. Finally, some diseases and blights can affect $A$. araucana stands (Valenzuela et al., 1997), so phytosanitary treatments should be implemented to improve the regeneration condition.

This study considered $A$. araucana sustainable management and not the complete cutting of $A$. araucana. The ecophysiographic approach for A. araucana regeneration has the advantage of simplicity and is easier to express as a mathematical function, which is used in a GIS for the decision-making process in forest management. Silvicultural actions can be conducted to improve the dynamic succession taking into account the current regeneration condition. On many private lands, the species harvested for sustainable forest management can provide an income to improve A. araucana landscapes (Drake, 2004).

The future sustainability of $A$. araucana forests may require comprehensive action at the landscape level. Given the current budgetary constraints, measures for landscape conservation acquire a prominent role. An ecophysiographic approach for $A$. araucana regeneration management may assure the sustainability management of some emblematic stands. The final model should depend on the available data and on the specific study aims. Statistical evaluation and spatial prediction are useful in the search for the best modeling 
approach. GIS increases the flexibility of this methodology, thus enabling an extrapolation to other territories. However, one should not forget to consider the particular characteristics of each area. Therefore, the use of an ecophysiographic approach should aid managers in developing different management strategies for native forest conservation.

\section{Acknowledgments}

This research was partially supported by grant No. 207.141.018-1.0 from the Research Service of Concepción University (Chile) and by grant B/6585/06 of the Spanish Agency of International Cooperation (AECI) from the Ministry for Foreign Affairs and Cooperation (Spain).

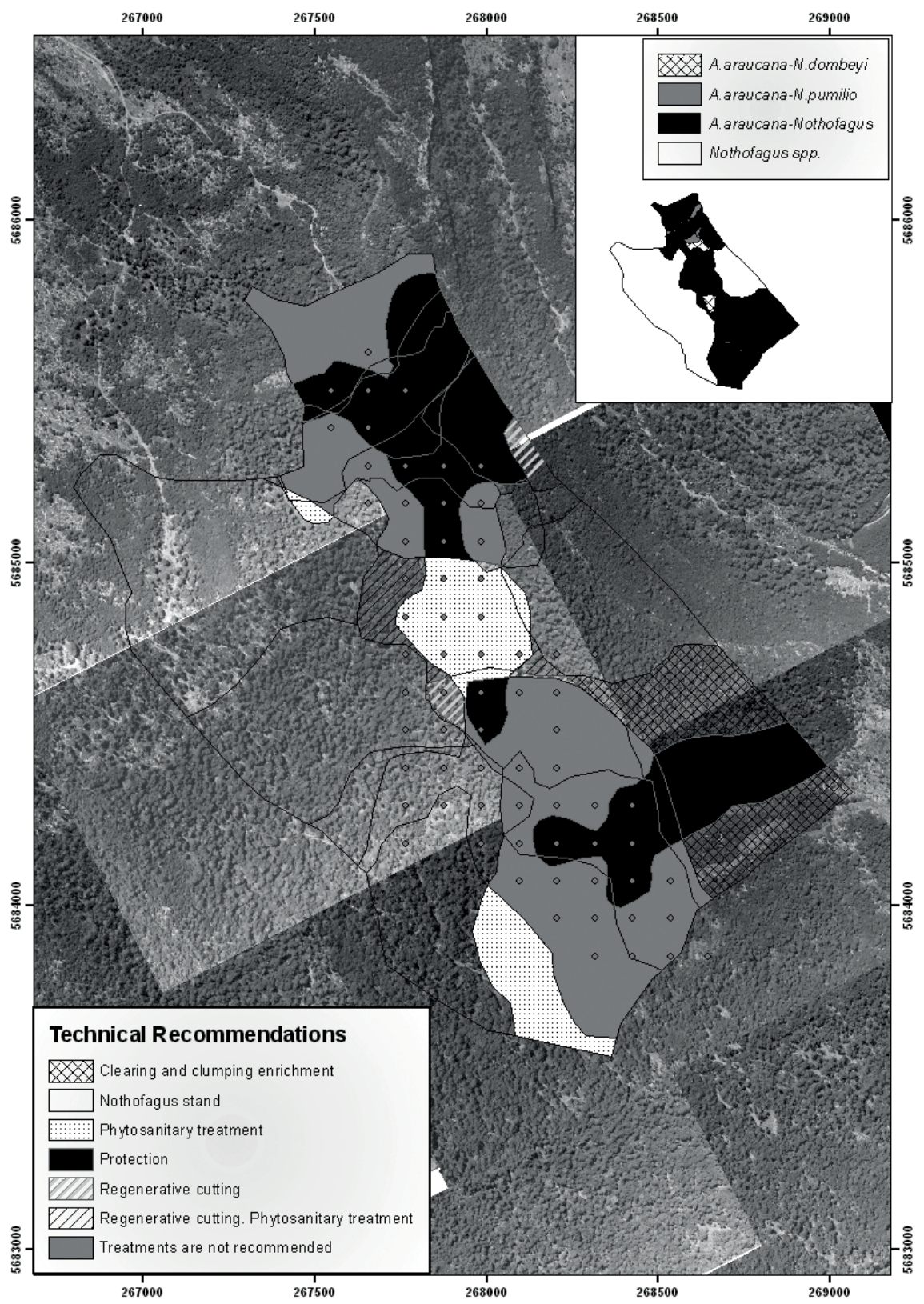

Figure 2. Technical recommendations based on the geostatistical methods (meters). 
Table 7. Technical recommendations based on ecophysiographic variables.

\begin{tabular}{|c|c|c|c|c|}
\hline $\begin{array}{l}\text { Regeneration } \\
\text { condition }\end{array}$ & Slope $(\%)$ & $\begin{array}{l}\text { Seedling tree presence } \\
(50-100 \mathrm{~cm} \text { in dbh })\end{array}$ & $\begin{array}{l}\text { A. araucana } \\
\text { density }\end{array}$ & Technical recommendations \\
\hline Good & Indifferent & Indifferent & Indifferent & Protection \\
\hline Medium & $>15$ & Yes & Low or Medium & Protection \\
\hline Medium & $>15$ & No & Low & Protection \\
\hline Medium & $>15$ & No & Medium or High & Protection \\
\hline Medium & $<15$ & No & Low & Regenerative cutting (Nothofagus) \\
\hline Medium & $<15$ & No & Medium & $\begin{array}{c}\text { Improvement cutting (Nothofagus) Phytosanitary } \\
\text { treatment (A. araucana) }\end{array}$ \\
\hline Medium & $<15$ & Yes & Medium & Phytosanitary treatment (A. araucana) \\
\hline Poor or None & $>15$ & No & Indifferent & Treatments are not recommended \\
\hline Poor or None & $>15$ & Yes & Low or Medium & Treatments are not recommended \\
\hline Poor or None & $<15$ & No & Low & Clearing and clumping enrichment \\
\hline Poor or None & $<15$ & No & Medium & $\begin{array}{c}\text { Regenerative cutting (Nothofagus) Phytosanitary } \\
\text { treatment (A. araucana) }\end{array}$ \\
\hline Poor or None & $<15$ & No & High & Phytosanitary treatment (A. araucana) \\
\hline Poor or None & $<15$ & Yes & Low & Clearing and clumping enrichment \\
\hline Poor or None & $<15$ & Yes & Medium & Regenerative cutting (Nothofagus) \\
\hline Poor or None & $<15$ & Yes & High & Phytosanitary treatment (A. araucana) \\
\hline
\end{tabular}

Good regeneration level: $>700$ seedlings per hectare; Medium regeneration level: between 400 and 700 seedlings per hectare; Poor regeneration level: $<400$ seedlings per hectare. Low stand density: $<50$ trees ha ${ }^{-1}$; Medium stand density: between 50 and 100 trees ha ${ }^{-1}$; and High stand density: $>100$ trees ha ${ }^{-1}$.

\section{Resumen}

F. Drake, J.R. Molina y M.Á. Herrera. 2012. Una aproximación ecofisiográfica para el manejo de la regeneración de Araucaria araucana. Cien. Inv. Agr. 39(1): 159-176. Los bosques templados chilenos están dominados por especies del género Nothofagus y Araucaria araucana. El valor cultural y los servicios y bienes ambientales asociados a la presencia de A. araucana juegan un papel esencial en la conservación del bosque nativo, a pesar de que no se encuentra bajo riesgo inminente de extinción. Su conservación está sujeta a un gran debate debido a su prohibición de manejo y a la limitada regeneración existente en algunas áreas debido a su bajo crecimiento, la competición existente en el dosel arbóreo y la presencia de un denso sotobosque. Todas estas características hacen a esta especie muy susceptible a perturbaciones como el ganado doméstico, la fauna silvestre y la presión humana. En este sentido, el manejo sustentable de los bosques de A. araucana requiere de la evaluación del estado de su regeneración. El objetivo de esta investigación fue aplicar técnicas de análisis multivariable con objeto de encontrar los parámetros más revelantes en la regeneración de $A$. araucana. Las técnicas utilizadas fueron el Análisis de Componentes Principales (ACP), el modelo de regresión mediante la eliminación de variables y el modelo Maxent. Mediante el análisis ACP fue posible reducir el modelo a seis variables con una explicación de la varianza superior al 75\%. El modelo de regresión multivariable, conocido como "Modelo 7", alcanzó el mayor resultado a tenor de la relación existente entre el coeficiente de determinación y el tamaño del modelo (número de variables independientes). La incorporación del concepto de máxima entropía mejoró la representatividad del modelo. La integración de las diferentes metodologías estadísticas y los Sistemas de Información Geográfica (SIG) permitió obtener una predicción espacial. Los SIG incrementan la flexibilidad del modelo propuesto permitiendo su extrapolación a otras áreas bajo diferentes escalas espaciales y temporales.

Palabras clave: Árbol semillero, especies de Nothofagus, establecimiento de plántulas, modelo Maxent. 


\section{References}

Aagesen, D.L. 1998. Indigenous resource rights and conservation of the monkey puzzle tree (Araucaria araucana, Araucariaceae): a case study from southern Chile. Economic Botany 52: 146-160.

Aagesen, D.L. 2004. Burning monkey-puzzle: native fire ecology and forest management in northern Patagonia. Agriculture and Human Values 21: 233-242.

Azocar, G., R. Sanhueza, M. Aguayo, H. Romero, and M. Muñoz. 2005. Conflicts for control of Mapuche-Pehuenche land and natural resources in the Biobío highlands. Journal of Latin American Geography 4: 57-76.

Baldwin, R.A. 2009. Use of maximum entropy modeling in wildlife research. Entropy 11: 854-866.

Bekessy, S.A., A. Lara, M.E. González, M. Cortés, L. Gallo, A.C. Premoli, and A.C. Newton. 2004. Variación en Araucaria araucana (Mol.) K. Koch (Araucaria o Pehuén). In: Donoso, C., A. Premoli, L. Gallo, R. Ipinza (eds.). Variación intraespecífica en las especies arbóreas de los bosques templados de Chile y Argentina. Santiago, Chile. Editorial Universitaria. p. 215-231.

Bengoa, J. 2000. Historia del pueblo Mapuche: siglo XIX y XX. Editorial Lom. Santiago, Chile. 423 pp.

Bond, W.J. 1989. The tortoise and the hare: ecology of angiosperm dominance and gymnosperm persistence. Biological Journal of the Linnean Society 36: 227-249.

Braun-Blanquet, J. 1979. Fitosociología. Edit. Blume. Madrid, España. 820 pp.

Burnham, K.P., and D.R. Anderson. 2002. Multimodel inference-understanding $\mathrm{AIC}$ and $\mathrm{BIC}$ in model selection. Sociological Method \& Research 33: 261-304.

Burns, B. 1991. The Regeneration Dynamics of Araucaria araucana. Ph.D. Thesis. Boulder, USA. University of Colorado. 211 pp.

Burns, B. 1993. Fire-Induced dynamics of Araucaria araucana - Nothofagus antarctica Forest in the Southern Andes. Journal of Biogeography 20: 669-685.

Caro, M. 1995. Producción y dispersión de semillas de Araucaria araucana (Mol.) C. Koch. en Lonqui- may. Facultad de Ciencias Agrarias y Forestales. Santiago, Chile. Universidad de Chile. 66 pp.

Cavieres, A. 1987. Estudio de crecimiento de Araucaria araucana (Mol.) C. Koch. en un bosque virgen de Araucaria-Lenga. Tesis de Grado. Facultad de Ciencias Forestales. Universidad de Concepción. Concepción, Chile. 98 pp.

Condés, S., and J. Martínez-Millán. 2001. Optimización del tamaño de la parcela de muestreo mediante simulación del inventario forestal. II Congreso Forestal Español. Granada, Spain. Tomo 4: 21-27.

Consejería de Medio Ambiente. 2004. Manual de ordenación de Montes de Andalucía. Consejería de Medio Ambiente. Junta de Andalucía. Sevilla, Spain. 356 pp.

Costa, G., C. Nogueira, R. Machado, and G. Colli. 2010. Sampling bias and the use of ecological niche modeling in conservation planning: a field evaluation in a biodiversity hotspot. Biodiversity and Conservation 19: 883-899.

Divasto, A.F. 2003. Caracterización de la regeneración natural de Araucaria araucana (Mol.) C. Koch. en el sector Pehuenco Parque Nacional de Nahuelbuta. Facultad de Ciencias Forestales. Universidad de Concepción. Santiago, Chile. 35 pp.

Donoso, C. 2008. Ecología forestal: el bosque y su medio ambiente. Santiago, Chile. Editorial Universitaria. $368 \mathrm{pp}$.

Donoso, C., M. González, M. Cortés, C. González, P. Donoso, and M. Hernández. 2008. Poblaciones de araucaria enana (Araucaria araucana) en la Cordillera de Nahuelbuta, Chile. Bosque 29: 170-175.

Donoso, C. 2006. Las especies arbóreas de los Bosques Templados de Chile y Argentina. Autoecología. Valdivia Chile, Marisa Cúneo Ediciones. $678 \mathrm{pp}$.

Donoso, C., and A. Lara. 1995. Utilización de los bosques nativos de Chile: pasado, presente y futuro. In: Armesto, J, C. Villagrán, and M. Arroyo (ed.). Ecología de los bosques nativos de Chile. Segunda edición. Santiago, Chile. Editorial Universitaria. p. 363-385.

Donoso, C. 1993. Bosques templados de Chile y Argentina: Variación, estructura y dinámica. Ter- 
cera edición. Santiago, Chile. Editorial Universitaria. 484 pp.

Drake, F., M.A. Martín, M.A. Herrera, J.R. Molina, F. Drake-Martín, and L.M. Martín. 2009. Networking sampling of Araucaria araucana (Mol.) K.Koch in Chile and the bordering zone of Argentine: implications for the genetic resources and the sustainable management. IForest 2: 207212.

Drake, F., M. A. Herrera, and E. Acuña. 2005. Propuestas para el manejo sostenible de Araucaria araucana (Mol.) K. Koch. Bosque 26: 23-32.

Drake, F. 2004. Uso sostenible en bosques de Araucaria araucana (Mol.) K. Koch. Aplicación de modelos de gestión. Doctoral Thesis. Córdoba, España. University of Córdoba. 318 pp.

Enright, N.J., J. Odien, and L.S. Rigg. 1999. Dynamics of forests with Araucariaceae in the western Pacific. Journal of Vegetation Science 10: $793-$ 804.

Enright, N.J., and R.S. Hill. 1995. Ecology of southern conifers. Melbourne, Australia. Melbourne University Press. 342 pp.

Finckh, M. 1996. Die wälder des Villarrica-Nationalparks (Südchile) -lebensgemeinschaften als grundlage für ein schutzkonzept. Cramer Verlag. Berlin-Stuttgart, Deutschland. 181 pp.

Finckh, M., and A. Paulsch. 1995. The ecological strategy of Araucaria araucana. Flora 53: 365-366.

Freese, F. 1961. Relation of plot size to variability: an approximation. Journal of Forestry 59(9): 679.

González, A.H. 1998. Análisis de la densidad y crecimiento de la regeneración de un bosque de Araucaria bajo distintas intensidades de corta de selección. Facultad de Ciencias Forestales. Universidad de Chile. Santiago, Chile. 79 pp.

González, M.E., T. Veblen, and J. Sibold. 2010. Influence of fire severity on stand development of Araucaria araucana-Nothofagus pumilio stands in the Andean cordillera of south-central Chile. Austral Ecology 35: 597-615.

González, M.E., and T. Veblen. 2007. Incendios en bosques de Araucaria araucana y consideraciones ecológicas al madereo de aprovechamiento en áreas recientemente quemadas. Revista Chilena de Historia Natural 80: 243-253.
González, M.E., T. Veblen, and J. Sibold. 2005. Fire history of Araucaria - Nothofagus forests in Villarrica National Park, Chile. Journal of Biogeography 32: 1187-1202.

Heusser, C., J. Rabassa, A. Brandani, and R. Stuckenrath. 1988. Late-holocene vegetation of the Andean Araucaria Region, Province of Neuquen, Argentina. Mountain Research and Development 8: 53-63.

Hoffmann, A., M. Sierra, C. Prosser, and M. Del Valle. 2001. Enciclopedia de los Bosques Chilenos. Santiago, Chile. Gráfica Andes. 351 pp.

IUCN. 1996. World list of threatened trees. International Union for the Conservation of Nature, Gland, Switzerland (IUCN). Available online at: http://www.iucn.org/about/work/programmes/ species/red_list/ (Website accessed: March 30, 2007).

Kuha, J. 2004. AIC and BIC - comparisons of assumptions and performance. Sociological Methods \& Research 33: 188-229.

Ladio, A.H. 2001. The maintenance of wild edible plant gathering in a Mapuche community of Patagonia. Economic Botany 55: 243-254.

León, E.M., and D. Villarroel. 2004. Dinámica regeneración post-incendio de Araucaria araucana (Mol.) K. Koch en la Cordillera Andina de la IX Región. Tesis de Grado. Facultad de Ciencias Forestales. Universidad de Concepción. Concepción, Chile. 48 pp.

Maggini, R., A. Lehmann, E. Zimmermann, and A. Guisan. 2006. Improving generalized regression analysis for the spatial prediction of forest communities. Journal of Biogeography 33: 17291749.

Maletti, E. 1997. El Pehuén, Araucaria araucana (Mol.) K. Koch. Caviahue, Argentina. Editorial APPCC (Administración Parque Provincial Copahue Caviahu). 31 pp.

Marticorena, C., and M. Quezada. 1985. Catálogo de flora vascular de Chile. Gayana Botánica 42: 5-155.

Montaldo, P. 1974. La bio-ecología de la Araucaria araucana (Mol.) K. Koch. Instituto Forestal Latino-Americano de Investigación y Capacitación 46: $3-55$ 
Moreno, R., R. Zamora, J.R. Molina, A. Vasquez, and M.A. Herrera. 2011. Predictive modelling of microhabitats for endemic birds in South Chilean temperate forests using maximum entropy (Maxent). Ecological Informatics 6: 364-370.

Mota, J., F. Pérez-García, M. Jiménez, J. Amate, and J. Peña. 2002. Phytogeographical relationships among high mountains areas in the Baetic Ranges (South Spain). Global Ecology and Biogeography 11: 497-504.

Mujica, R., H. Schmidt, H. El Kateb, and R. Mosandl. 2009. Evaluación de tratamientos silvícolas en bosques de Araucaria araucana en el sur de Chile. Proceedings of the XII World Forestry Congress. Buenos Aires, Argentina. pp. 1-14.

Mutarelli, E. 1966. Algunos aspectos dasométricos y dendrológicos de Araucaria araucana (Mol) K. Koch. Revista Forestal Argentina 3: 96-103.

Otero, L. 2006. La huella del fuego. Historia de los bosques nativos. Doblamiento y cambios en el paisaje del sur de Chile. Santiago, Chile. Editorial Pehuén. 171 pp.

Peterson, A., and Y. Nakazawa. 2008. Environmental data sets matter in ecological niche modelling: an example with Solenopsis invicta and Solenopsis richteri. Global Ecology and Biogeography 17:135-144.

Phillips, S., R. Anderson, and R. Schapire. 2006. Maximum entropy modelling of species geographic distributions. Ecological Modelling 190: 231-259.

Rechene, C., J. Bava, and R. Mujica. 2003. Los bosques de Araucaria araucana en Chile y Argentina. Deutsche Gesellschaft für. Eschborn. República Federal de Alemania. 158 pp.

Rodríguez, R., O. Matthei, and M. Quezada. 1983. Flora arbórea de Chile. Primera edición. Concepción, Chile. Editorial de la Universidad de Concepción. 28 pp.

Sanguinetti, J., and T. Kitzberger. 2010. Factors controlling seed predation by rodents and non-native Sus scrofa in Araucaria araucana forests: potential effects on seedling establishment. Biological Invasion 12: 689-706.

Sanguinetti, J., and T. Kitzberger. 2009. Araucaria araucana temporal and spatial seedling estab- lishment patterns: masting, seed predation and understory vegetation effects. Revista Chilena de Historia Natural 82: 319-335.

Sanguinetti, J., and T. Kitzberger. 2008. Patterns and mechanisms of masting in the large-seed southern conifer Araucaria araucana. Austral Ecology 33: 78-87.

Schmidt, H., and A. Lara. 1985. Descripción y potencialidad de los bosques nativos de Chile. Ambiente y Desarrollo 1: 91-108.

Schmidt, H., M. Toral, and P. Burgos. 1980. Aspectos de estructura y de regeneración natural para el manejo silvícola de los bosques de AraucariaLenga de Chile. IUFRO Meeting: Forestry Problems of the Genus Araucaria. Curitiba, Brazilien 59-166

Schmidt, H. 1977. Dinámica de un bosque virgen de Araucaria-Lenga (Chile). Bosque 2: 3-11.

Schwarz, P.A., T.J. Fahey, and C.E. McCulloch. 2003. Factors controlling spatial variation of tree species abundance in a forested landscape. Ecology 84: 1862-1878.

Shepherd, J., R. Ditgen, and J. Sanguinetti. 2008. Araucaria araucana and the Austral parakeet: predispersal seed predation on a masting species. Revista Chilena de Historia Natural 81: 395-401.

Swets, J.A. 1988. Measuring the accuracy of diagnostic systems. Science 240: 1285-1293.

Torrejon, F., and M. Cisternas. 2003. Impacto ambiental temprano en la Araucanía deducido de crónicas españolas y estudios historiográficos. Bosque 24(3): 45-55.

Tortorelli, L.A. 1956. Maderas y bosques argentinos. Editorial ACME. SACI, Buenos Aires. Argentina. $910 \mathrm{pp}$.

Valenzuela, E., H. Peredo, and L. Vives. 1997. Determinaciones micológicas comentadas, en cuatro sectores del Parque Nacional Conguillío, IX Región, Chile. Bosque 18: 115-118.

Veblen, T. 1982. Regeneration patterns in Araucaria araucana forests in Chile. Journal of Biogeography 9: 11-28.

Veblen, T., B. Burns, T. Kitzberger, A. Lara, and R. Villalba. 1995a. The ecology of conifers of the southern South america. In: Enright N., and R. Hill (eds.). Ecology of the Southern Coni- 
fers. Parkville, Australia. Melbourne University Press. pp. 120-155.

Veblen, T., T. Kitzberger, B. Burns, and A. Rubertus. 1995b. Perturbaciones y dinámica de regeneración en bosques andinos del sur de Chile y Argentina. In: J. Armesto, C. Villagrán, and M. Arroyo (eds.). Ecología de los bosques nativos de Chile. Santiago, Chile. Editorial Universitaria. pp. 169-198.

Zeide, B. 1980. Plot size optimization. Forest Science 26: 251-257.

Zhang, L.J., J.H. Gove, and L.S. Heath. 2005. Spatial residual analysis of six modelling techniques. Ecological Modelling 186: 154-177. 